\title{
GLASS WASTE POWDER UTILIZATION IN HIGH PERFORMANCE CONCRETE
}

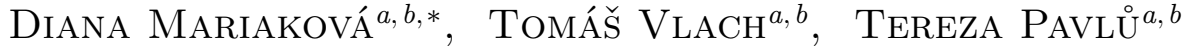 \\ ${ }^{a}$ Czech Technical University in Prague, Faculty of Civil Engineering, Thákurova 2077/7, 16629 Prague 6, Czech \\ Republic \\ ${ }^{b}$ Czech Technical University in Prague, University Centre for Energy Efficient Buildings, Třinecká 1024, 27343 \\ Buštěhrad, Czech Republic \\ * corresponding author: diana.mariakova@fsv.cvut.cz
}

\begin{abstract}
This paper deals with investigation of high-performance concrete (HPC) with full replacement of the silica powder by the waste glass powder. The silica powder was replaced by two types of the waste glass powder, originated from different sources (waste glass powder from grinding jewelry and milling of municipal waste glass). The properties of the waste glass powder were examined and compared with the silica powder. The mechanical and durability properties of three HPC mixtures were experimentally verified. The bulk density, flexural strength, and compressive strength were tested on beams $40 \times 40 \times 160 \mathrm{~mm}$ at age 28 and 60 days and after $0,25,50,75$ and 100 freeze-thaw cycles. There were observed slightly worse properties of mixtures with the waste glass powder in comparison with reference HPC.
\end{abstract}

KEYWORDS: Waste glass powder, high performance concrete, durability, mechanical properties.

\section{INTRODUCTION}

High-performance concrete (HPC) becomes very popular. HPC has been mostly used in the precast industry, for pedestrian footbridges. Nowadays, HPC is used in buildings structures (skyscrapers) or in transportation structures (bridges) [1]. Due to its excellent mechanical properties the HPC structures could be more subtle. This could lead to the raw materials saving.

The properties of HPC are suitable in many ways such as mechanical and durability properties. HPC is also possible to use in aggressive environment with aggressive substances such as sulphates or chlorides. Permeability of HPC is also very low 22. There is also the risk of carbonation of the concrete and further its corrosion due to presence of carbon dioxide in standard environment. For this reason, the utilization of HPC is appropriate as prevention against corrosion and concrete damage. Due to its excellent durability properties, the long lifespan of constructions is provided, despite exposure to aggressive conditions. The long lifespan and also lower material consumption of HPC structures is the main and most important advantages of this material. However, the primary raw materials which are used for HPC has high environmental impact such as $\mathrm{CO}_{2}$ emissions, energy and raw material consumption. The impact on the environment is an important question. Nevertheless, new tendencies are heading towards sustainable building and ecological materials. This is the reason why it is appropriate time to think about improving HPC in an environmentally friendly way.

Silica powder, using as inner filler in HPC, is possible to replace with glass powder, because of simi- lar properties. On one hand, the glass is a nondecomposable material which is necessary to landfilled. However, on the other hand, the material is almost $100 \%$ recyclable [3. Recycling is the necessary attitude for the next years. Along with recycling it is desirable to minimize the amount of waste [4].

There are several studies [5] 8 , that examine the possibility of using glass waste as a partial replacement of aggregate in concrete. It is possible to replace coarse aggregate or fine aggregate. The replacement ratio depends on particles size due to possibility of alkalisilica reaction (ASR). It is important to notice that on basis of alkali-silica reaction are significant only aggregates with amorphous silica 9 .

The utilization of waste glass as replacement of different constituents in concrete mixture has been investigated (aggregate replacement, inert filler, partial cement replacement etc.). The use of waste glass as partial replacement of coarse aggregate for ordinary concrete is possible way in some cases. There are several studies to examine a partial cement and quartz powder (fine fraction) replacement by waste glass powder in ordinary concrete or ultra-high performance concrete (UHPC) [8, 10. The utilization of waste glass powder as partial replacement in HPC has not been completely explored yet. For this reason, the aim of this investigation was to prove the use of waste glass powder as full replacement of silica powder in HPC. The experiments were focused on a verification of mechanical properties and durability of HPC with waste glass powder. The results were compared with the reference sample containing silica powder. 


\section{MAterials And Experimental PROGRAM}

Samples of waste glass powder was collected and examined. There were two types of waste glass - milled waste glass from municipal waste and grinding glass. Analysis were made - granulometry and chemical analysis. After that, the grain curves were investigated and compared with the reference sample - silica powder. The same thing was made with chemical composition. After completing analysis of waste glass powder, high performance concrete was made. The basic recipe was optimized in previous research project, cf. Table 1. The optimized recipe is used as the reference sample (A). After that, the optimized basic recipe was changed - replacing silica powder with grinding glass (sample B), then with the milled waste glass from municipal waste (sample $\mathrm{C}$ ). The weight of fine fraction stayed the same. There were two samples $(\mathrm{B}, \mathrm{C})$ which were examined and compared with reference sample (A). The differences were evident in the structure of concrete.

\begin{tabular}{|l|c|}
\hline Component & Quantity (kg/m $\mathbf{3})$ \\
\hline Cement I 42.SR & 680 \\
\hline Technical silica sand & 960 \\
\hline Silica powder (ground quartz) & $\mathbf{3 2 5}$ \\
\hline Silica fume (microsilica) & 175 \\
\hline Superplasticizers & 29 \\
\hline Water & 171 \\
\hline TOTAL & $\mathbf{2 3 4 0}$ \\
\hline
\end{tabular}

TABLE 1. Basic recipe of HPC - reference sample A

Size of prepared samples for tests of mechanical properties was $40 \times 40 \times 160 \mathrm{~mm}$. There were 54 samples made, 18 from each type. Samples 1-15 of each type was ready for tests after 28 days, samples 16-18 was ready for tests after 60 days. It was also meant to compare differences of the mechanical properties between 28-days-old concrete and 60-days-old concrete.

\subsection{Tests of Mechanical Properties}

Tests of mechanical properties were made using destructive methods. The tests were made on samples after 28 and 60 days. Prepared samples were examined to determine:

Compressive strength. The tested samples can be cubes, cylinders. In this paper, compressive strength was tested on fragments of samples $40 \times$ $40 \times 160 \mathrm{~mm}$. The tested surface $A_{c}$ was $40 \times 40 \mathrm{~mm}$. There are certain conditions to keep - about samples (EN 12350-1, EN 12390-1, EN 12390-2 or EN 125041 ), machine (EN 12390-4) and procedure.

Tensile bending strength. Tensile bending strength is described in CSN EN 12390-5 11. The test is realized on block specimens with dimension $40 \times 40 \times 160 \mathrm{~mm}$. Tensile bending strength is defined by three-point press according to ČSN EN
1015-11 12]. The test is over after the sample breaks. The highest force registered during the test is used for calculation tensile bending strength. It is always necessary to test at least three samples.

Freeze-thaw resistance. The tested samples are $40 \times 40 \times 160 \mathrm{~mm}$. This test was made following ČSN 73 1322. Cooling is done by air -4 hours to $-20^{\circ} \mathrm{C}$ and then 2 hours of warming up to $20^{\circ} \mathrm{C}$. The samples were tested in 25, 50, 75 and 100 cycles.

\section{Results And Discussion}

The following chapters describe the results and discussion of all tests.

\subsection{Chemical Analysis}

Chemical analysis of samples A, B and C were examined during the spring of 2017. Table 2 summarize the results.

There are differences such as similarities in chemical composition. After checking amount of $\mathrm{SiO}_{2}$ and $\mathrm{NaO}_{2}, \mathrm{CaO}$, it is possible to see difference in number - dozens of percent. Chemical composition has an impact to resulting properties. It is necessary to examine potential alkali-silica reaction. The topic of detailed examination of chemical composition could be used in the upcoming research.

\begin{tabular}{|l|c|c|c|}
\hline Symbol & $\begin{array}{c}\text { Sample } A- \\
\text { reference sample }\end{array}$ & $\begin{array}{c}\text { Sample B- } \\
\text { Grinding glass }\end{array}$ & $\begin{array}{c}\text { Sample C- } \\
\text { Milled waste glass }\end{array}$ \\
\hline $\mathrm{SiO}_{2}$ & $85.730 \%$ & $56.395 \%$ & $55.740 \%$ \\
\hline $\mathrm{Fe}_{2} \mathrm{O}_{3}$ & $0.677 \%$ & $0.757 \%$ & $1.044 \%$ \\
\hline $\mathrm{Al}_{2} \mathrm{O}_{3}$ & $0.234 \%$ & $3.260 \%$ & $2.224 \%$ \\
\hline $\mathrm{NaO}_{2}$ & $<0.014 \%$ & $26.736 \%$ & $19.220 \%$ \\
\hline $\mathrm{TiO}_{2}$ & $0.0654 \%$ & $0.0453 \%$ & $0.0748 \%$ \\
\hline $\mathrm{Ba}$ & $0.0322 \%$ & $0.219 \%$ & $0.1051 \%$ \\
\hline $\mathrm{P}_{2} \mathrm{O}_{5}$ & $0.0244 \%$ & $0.0868 \%$ & $0.0589 \%$ \\
\hline $\mathrm{CaO}$ & $<0.0014 \%$ & $3.0459 \%$ & $11.490 \%$ \\
\hline
\end{tabular}

TABLE 2. Results of chemical analysis.

\subsection{Particle Size Distribution}

The size of particle has the main impact to the results. With the growing particle size increases the potential risk of ASR. It would be convenient to consider another milling or regrinding of the particles to achieve appropriate size in next research. The comparison of particle size is attached in Graph 1 .

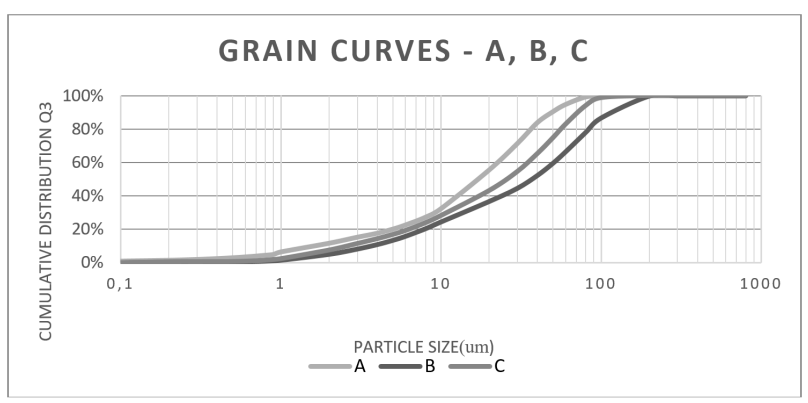

GRAPH 1. Comparison of particle size distribution. 


\subsection{Bulk Density}

Bulk density of the samples could have the main impact to the results. The porosity in the sample can change the compressive strength or the tensile bending strength values. This research used the same weight amount of waste glass powder to replace silica powder. It would be appropriate to try another attitude in next research - based on bulk density, calculate the appropriate amount of the replacement.

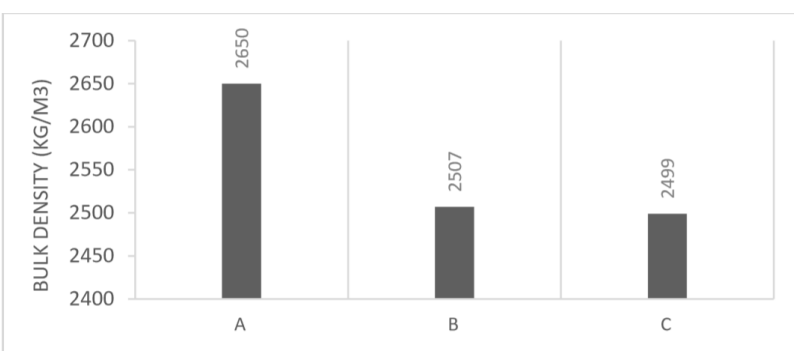

Graph 2. Bulk density of the samples A, B and C average values from 10 samples.

It is possible to see difference between samples B and $\mathrm{C}$ compared to sample A, cf. Graph 2 However, the difference is negligible - bulk density of sample $\mathrm{B}$ is $94,9 \%$, bulk density of sample $\mathrm{C}$ is $94,3 \%$ compared to sample A - considered as $100 \%$.

Bulk density of the concrete is calculated based on weight and volume. In Graph 3 note that the bulk density of the reference sample $\mathrm{A}$ is comparable with sample B and sample C.

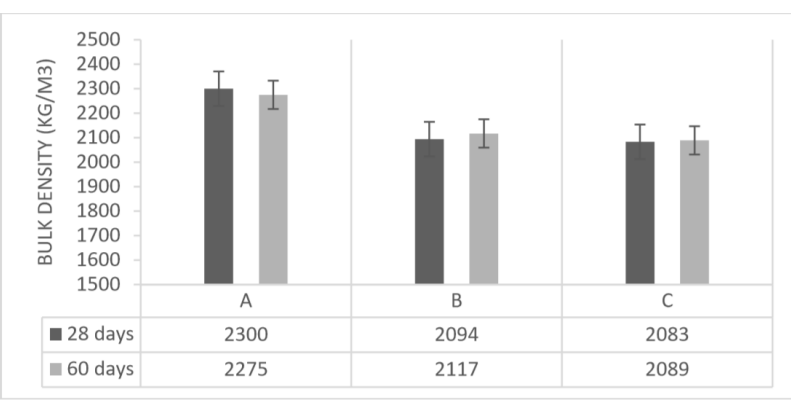

GRAPH 3. Bulk density of the concrete after 28 days and 60 days - average values from 3 samples.

Difference between samples B and C is less than $10 \%$ compared to reference sample $\mathrm{A}$ in all cases. Based on this knowledge, it is possible to compare the samples in following tests.

\subsection{Tensile Bending Strength}

Longer hardening time has a positive impact to the results - tensile bending strength increased after 60 days, cf. Graph 4 Nevertheless, the values between cycles are slightly different (with the increasing number of cycles the values are decreasing), but the impact of freezing cycles is not as big as the impact, for example, particle size or chemical composition.

Sample B achieved better results than sample C, it is probably caused due to the chemical composition. The values of sample B and C were $68 \%-88 \%$ compared to sample A (considered as $100 \%$ ). However, it would be appropriate to work on utilization of both samples in HPC and try to improve the results.

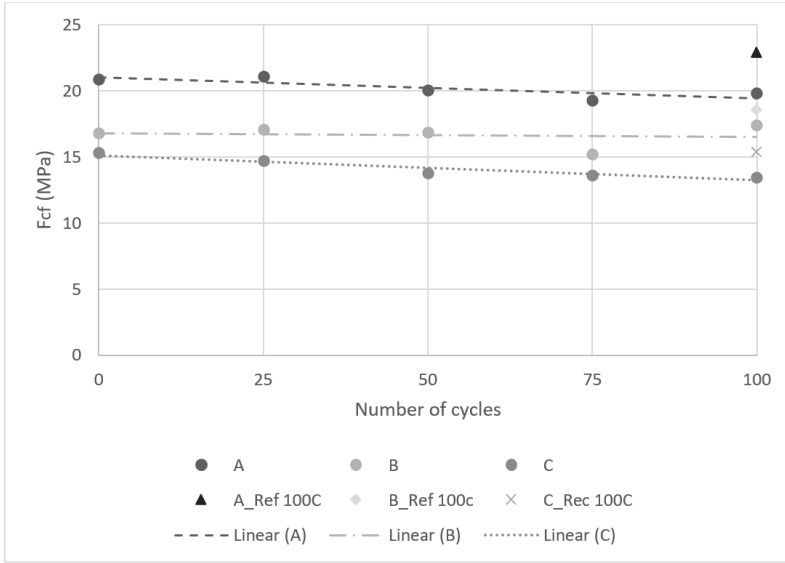

Graph 4. Comparison of tensile bending strength average values from 3 samples.

\subsection{Compression Strength}

Compressive strength values showed positive impact of longer hardening time - the results are better after 60 days (expect sample $\mathrm{A}$ - although it is reference sample, in this case it is a negligible value). It would be appropriate to make the other tests based on longer hardening time in next years.

The compressive strength values after freeze-thaw resistance tests are satisfying, cf. Graph 5 the values of sample B and $\mathrm{C}$ range from $70 \%$ to $79 \%$ compared to sample A (considered as 100\%). However, the values are decreasing (sample $\mathrm{A}, \mathrm{B}, \mathrm{C}$ ) - it is unusual for HPC.

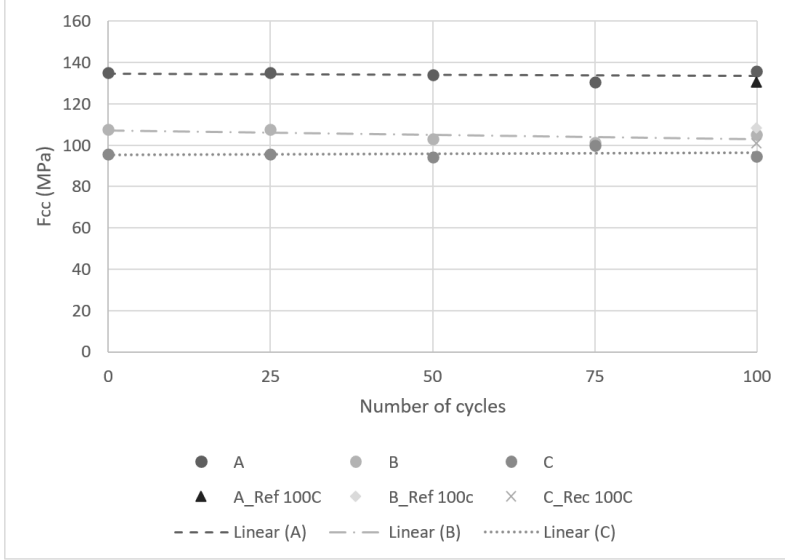

GRAPH 5. Comparison of compressive strength - average values from 3 samples.

\section{Conclusions}

Utilization of waste glass powder in high performance concrete was examined. Waste glass powder was used as replacement of silica powder in HPC. Mechanical 
and physical properties of concrete made with waste glass powder from different sources were investigated.

Two samples of high performance concrete contain waste glass powder were made, one sample of high performance concrete contains silica powder was made as well - the reference sample. Two waste glass powder samples were examined and compared to the reference sample.

First, the chemical composition was examined to find out the differences and similarities. There is a possibility to modify chemical composition to improve the results.

The particle size distribution was investigated, because the particle size has the main impact to the structure of the concrete and therefore the impact to the results as well. It would be appropriate to consider another milling to reach the right particle size - comparable to silica powder.

The bulk density of silica flour, glass powder and concrete was examined as well. The values were slightly different - it should not affect the results of the physical properties.

The tests to find out the compressive strength and the tensile bending strength were made. The results were compared to reference sample (contains silica powder).

There is a risk of an alkali-silica reaction, because of glass used in the HPC mixture. The freeze-thaw resistance tests confirmed that due to the dense HPC structure, the probability of the alkali-silica reaction was eliminated.

This study can be used as a basic for further work. The waste glass powder can be improved in different ways in next years and the utilization in HPC as inner filler is possible.

\section{ACKNOWLEDGEMENTS}

This work was supported by the Grant Agency of the Czech Technical University in Prague, grant No.
SGS17/010/OHK1/1T/11.

\section{REFERENCES}

[1] L. Myšíčková. Vlastnosti, zkoušení a využití uhpc v konstrukcích. Brno: Vysoké učení technické v Brně, Fakulta stavební, Ústav stavebního zkušebnictví 2011.

[2] High performance concrete. http://civil-resources.blogspot.be/2010/06/ high-performance-concrete.html.

[3] J. Vacková. Problematika třídění odpadu u různých věkových kategorií obyvatel. České Budějovice 2013.

[4] D. Vávrová. Recyklace skla 2011.

[5] A. Mohajerani, J. Vajna, T. H. H. Cheung, et al. Practical recycling applications of crushed waste glass in construction materials: A review. Construction and Building Materials 156:443-467, 2017.

[6] J. Khatib, E. Negim, H. Sohl, et al. Glass powder utilisation in concrete production. European Journal of Applied Sciences 4(4):173-176, 2012.

[7] I. B. Topcu, M. Canbaz. Properties of concrete containing waste glass. Cement and concrete research 34(2):267-274, 2004.

[8] Z. Z. Ismail, E. A. Al-Hashmi. Recycling of waste glass as a partial replacement for fine aggregate in concrete. Waste management 29(2):655-659, 2009.

[9] R. Breitenbücher. Alkalicko-křemičitá reakce-důsledky pro cementobetonové kryty. Strasse+ Autobahn 4, 2006.

[10] N. Soliman, A. Tagnit-Hamou. Development of ultra-high-performance concrete using glass powder-towards ecofriendly concrete. Construction and building materials 125:600-612, 2016.

[11] ČSN EN 12390-5. Testing of hardened concrete-part 5: Bending strength. Czech Standardization Institute, Prague 2007.

[12] ČSN EN 1015-11. Zkušební metody malt pro zdivo. 